\title{
Canadian Digestive Health Foundation Public Impact Series: Gastroesophageal reflux disease in Canada: Incidence, prevalence, and direct and indirect economic impact
}

\author{
Richard N Fedorak MD FRCPC ${ }^{1}$, Sander Veldhuyzen van Zanten MD FRCPC ${ }^{1}$, Ron Bridges MD FRCPC ${ }^{2}$
}

\begin{abstract}
RN Fedorak, S Veldhuyzen van Zanten, R Bridges. Canadian Digestive Health Foundation Public Impact Series: Gastroesophageal reflux disease in Canada: Incidence, prevalence, and direct and indirect economic impact. Can J Gastroenterol 2010;24(7):431-434.

The Canadian Digestive Health Foundation initiated a scientific program to assess the incidence, prevalence, mortality and economic impact of digestive disorders across Canada. The current article presents the updated findings from the study concerning gastroesophageal reflux disease - a condition that develops when the reflux of stomach contents causes troublesome symptoms and/or complications (Montreal definition).
\end{abstract}

Key Words: Acid reflux; Chronic disease; Gastroesophageal reflux disease; GERD; Heartburn; Pyrosis
Le reflux gastro-œsphagien au Canada : Incidence, prévalence et impact économique direct et indirect selon la série Impact public de la Fondation canadienne pour la promotion de la santé digestive

La Fondation canadienne pour la promotion de la santé digestive a mis sur pied un programme scientifique dans le but de mesurer l'incidence, la prévalence, la mortalité et l'impact économique associés aux maladies digestives au Canada. Cet article présente les conclusions mises à jour de l'étude sur le reflux gastro-œsophagien, une maladie caractérisée par le reflux du contenu gastrique et qui occasionne des symptômes et/ou des complications ennuyeux (d'après la définition de Montréal).

\begin{tabular}{|c|c|c|c|}
\hline $\begin{array}{l}\text { The Canadian Digestive Health Foundation (CDHF) } \\
\text { launched a scientific project to define the incidence, preva- }\end{array}$ & \multicolumn{3}{|c|}{$\begin{array}{l}\text { TABLE } 1 \\
\text { Overview of gastroesophageal reflux disease }\end{array}$} \\
\hline lence, mortality and economic impact of digestive & Common symptoms & Uncommon symptoms & Complications \\
\hline disorders was compiled through systematic reviews, government & Regurgitation & throat & Esophageal stricture \\
\hline and websites. This infor & Localized or diffuse or & Difficulties swallowing & Ulceration and bleeding \\
\hline "Establishing Digestive Health as a Priority for Canadians, The & retrosternal pain or & Asthma & Barrett's epithelium \\
\hline $\mathrm{Di}$ & Sleep disturbance & Nausea & inoma \\
\hline The CDHF Public Impact Series presents a full compilation of & Postprandial fullness & Vomiting & Upper respiratory \\
\hline $\begin{array}{l}\text { the available statistics regarding the impact of digestive disor- } \\
\text { ders in Canada. }\end{array}$ & $\begin{array}{l}\text { Upper abdominal } \\
\text { distension }\end{array}$ & & $\begin{array}{l}\text { complaints } \\
\text { (eg, wheezing, chronic }\end{array}$ \\
\hline Gastroesophageal reflux disease (GERD) is a condition that & Early satiety & & $\begin{array}{l}\text { coughing } \\
\text { or throat clearing) }\end{array}$ \\
\hline
\end{tabular}
develops when the reflux of stomach contents causes troublesome symptoms and/or complications (Montreal definition). The most frequent complication is inflammation leading to esophagitis, stricture, Barrett's esophagus and adenocarcinoma (Table 1). Most people consider symptoms troublesome if they are mild and occur more than once a week, or at least once a week for moderate to severe symptoms. Many individuals selfmedicate with over-the-counter medications such as antacids (1). Although the cause or origin of this chronic disease is not well understood, there are certain risk factors associated with GERD development (Table 2). It has been well documented

that individuals with untreated GERD experience a significant decrease in their quality of life and have a higher risk for developing serious complications.

The Canadian Association of Gastroenterology has created an evidence-based practice guideline for the diagnosis and treatment of GERD (2). Initial diagnosis of GERD is made if the symptomatic patient responds to antacid therapies such as $\mathrm{H}_{2}$-receptor antagonists or the more effective - but more costly - proton pump inhibitors. Patients who experience

${ }^{1}$ Division of Gastroenterology, University of Alberta, Edmonton; ${ }^{2}$ Division of Gastroenterology, University of Calgary, Calgary, Alberta

Correspondence: Dr Richard N Fedorak, Division of Gastroenterology, University of Alberta, 2-14A Zeidler Building,

Edmonton, Alberta T6G 2X8. Telephone 780-492-6941, fax 780-492-8121, e-mail richard.fedorak@ualberta.ca

Received for publication May 21, 2010. Accepted May 24, 2010 
TABLE 2

Risk factors for developing gastroesophageal reflux disease

Obesity (24)

Smoking (25)

Age (24)

Parental or family history of gastrointestinal diseases (24)

Esophageal stricture (24)

High-cholesterol diet (25)

Lung transplantation (26)

Cystic fibrosis (27)

no symptom improvements are commonly referred to gastroenterologists for testing to eliminate other possible causes. A diagnosis of refractory GERD is made if no other causes are identified and a patient's symptoms persist in spite of proton pump inhibitor dose escalation to twice daily; typically, this represents $19 \%$ to $32 \%$ of GERD patients $(3,4)$. Surgical interventions (eg, Nissen fundoplication) can be associated with significant symptom improvements for adults with refractory or moderate to severe GERD.

Increased awareness of GERD is necessary to improve the health of Canadians who may be suffering in silence. Much information has already been obtained in other western cultures, which can be placed into a Canadian context; to date, however, this has yet to be completed. By understanding the epidemiological and economic impact of GERD on Canadians and our society, health care professionals, policy makers and the public at large can take the next steps in developing a disease management priority list.

\section{METHODS}

A systematic literature review was conducted to retrieve peer-reviewed, English language scholarly articles using the PubMed, Medline, EMBASE and Scopus databases. The search terms "reflux disease", "GERD" and "GORD" were used, with specific focus on epidemiological and economic studies from developed countries. Additional information was retrieved from government sources, the WHO and not-forprofit organizations.

\section{Incidence (Table 3)}

\section{RESULTS}

Only two longitudinal studies $(5,6)$ examining the incidence of GERD in adults have been conducted. The first (5) was conducted in the United Kingdom (UK) and relied on firsttime physician diagnoses of GERD, esophagitis, esophageal inflammation or heartburn as recorded in the General Practice Research Database in 1996. The authors found that the annual incidence of GERD was 4.5 per 1000 person-years (95\% CI 4.4 to 4.7 ). The second study (6) used the Medicaid database for the state of Georgia (USA) to identify new cases of GERD based on filled prescriptions. The incidence of 5.4 cases per 1000 person-years was very similar to the incidence reported in the UK study. It should be noted that both studies only captured the portion of GERD sufferers who sought medical assistance for their symptoms, implying that this figure is much larger, but it is unclear by how much. There are no prospective published incidence studies of GERD in the Canadian population.
TABLE 3

Canadian incidence, prevalence and economic impact of gastroesophageal reflux disease

\begin{tabular}{lll}
\hline & Published data (reference) & Canadian exposures* \\
\hline Incidence & & \\
Adult & $4.5-5.4 / 1000$ person-years $(5,6)$ & 170,000 per year (19) \\
Pediatric & $9-10 / 1000$ person-years $(9)$ & 56,000 per year (19) \\
Prevalence & $10 \%-20 \%(11)$ & $3.4-6.8$ million \\
& & persons (19) \\
Direct costs & $\$ 52,235,910$ per year $(16)$ & \\
Indirect costs & $\sim 6.7$ h per week lost work (20) & \\
\hline
\end{tabular}

${ }^{\star}$ Extrapolated to a population of 34 million

Extrapolating the UK and USA incidence rates, and using an estimate population of 34 million within Canada, every year, a minimum of 170,000 individuals will be newly diagnosed with GERD. Importantly, the peak age distribution of GERD is 60 to 70 years, indicating that the incidence rate is tightly linked with age in Western populations (7). Between 2010 and 2040, the proportion of Canadian seniors is projected to nearly double, suggesting that the GERD incidence rate will likely increase sharply rather than stabilize or decrease (8).

Using an American administrative claims database (9), the diagnosis rate of pediatric GERD or acid-related disease was $0.6 \%$ to $1.0 \%$ per year. Between 1999 and 2005, the incidence rate of newly diagnosed GERD in children younger than one year of age increased sharply from $3.4 \%$ to $12.3 \%$. This increase was largely attributed to increased awareness in addition to cases of either overdiagnosis or misdiagnosis of eosinophilic esophagitis. Because this study's findings corroborate those from another (10) investigating prescription acid suppression therapy in pediatrics and corresponds to the period in which childhood obesity has leapt dramatically, it is likely that these findings are not artefacts of either poor study design or interpretation.

Sixteen per cent of the Canadian population of 34 million are zero to 14 years of age and, at an incidence rate of $1 \%$, 56,000 Canadian children are projected to be newly diagnosed with GERD each year (11). The majority of these patients will be younger than one year of age. Both prescription medicines and over-the-counter antacids - many of which are in a solid form unsuitable for the very young and for which there is negligible evidence supporting their efficacy in placebo-controlled trials (9) - are not approved for use in children.

\section{Prevalence (Table 3)}

GERD is a chronic disease that can last for up to 18 years (12). Between 34\% and $41 \%$ of GERD patients recall experiencing GERD-like symptoms for more than 10 years before diagnosis (12). This long-term cumulative effect results in an increasing patient population year after year. In Western countries, the prevalence range for GERD is $10 \%$ to $20 \%$ of the population (3.4 million to 6.8 million Canadians). A uniquely Canadian consideration is the long life expectancy relative to other countries. The combination of long life expectancy and an aging population will increase the overall number of GERD patients in the years to come $(8,13)$. There are no data that support sex predominance with regard to GERD.

Pediatric GERD patients have been documented, with most cases spontaneously resolving within a few months or years 


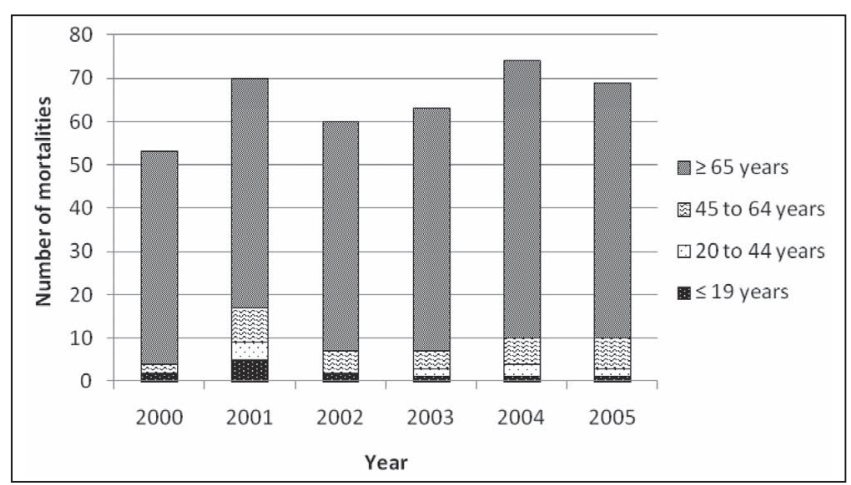

Figure 1) Gastroesophageal reflux disease-related mortalities per year categorized according to age group

after birth. Surgery is not recommended, especially because proton pump inhibitors are well tolerated in pediatric patients. The treatment goal is to eliminate GERD symptoms, then to step down therapy to an 'as-required' basis (9).

\section{Mortality}

Because GERD is often not the primary cause of death but a secondary or underlying condition, its role is often not recorded, although it may be a significant contributor. Between 2000 and 2005, there was an annual mean of 65 mortalities caused primarily by GERD (Figure 1) (14). As with incidence and prevalence, there is no apparent sex discrimination.

\section{Economics}

Direct costs: In 2004/2005, the Canadian health care system spent a mean of $\$ 6,915$ per patient for the 7554 patients who had a primary diagnosis of diseases of the esophagus and associated complications, for a total of $\$ 52,235,910$ (15).

In Canada, the first $\mathrm{H}_{2}$-receptor antagonist was licensed for sale over the counter in June 1996 (16). Although not as effective as proton-pump inhibitors (17), GERD patients can self-medicate with $\mathrm{H}_{2}$-receptor antagonists; however, they incur considerable personal expense and risk the development of GERD-related health complications (16). Proton pump inhibitor therapy has grossed in excess of $\$ 10$ billion in global sales since its introduction in 1988 (18). Worldwide, there have been more than 720 million prescriptions written for proton pump inhibitor therapy (18). In 2004, there were 12.4 million prescriptions for proton pump inhibitors - as prescribed by MDs (19) (Figure 2). Canadian cost estimates for a 28-day supply of proton pump inhibitor therapy range from $\$ 40$ to $\$ 70$ (19).

\section{Indirect costs}

In 2005, a Canadian study (20) of medically diagnosed GERD patients $(n=217)$ with moderate-to-severe symptoms was conducted to ascertain the impact of the disease. Of the 173 patients who were employed, $6.7 \mathrm{~h}$ of work time was lost each week due to GERD symptoms (16\% lost work time, 95\% CI $12.9 \%$ to $18.8 \%)$. Activity impairment also affected as much as $21 \%$ of nonwork-related activities (95\% CI $18.0 \%$ to $24.0 \%$ ). This is explained by the significantly lower scores for the physical and mental component summaries of the Medical Outcomes Study Short Form-36 Health Survey of the cohort compared with the Canadian population $(\mathrm{P}<0.001)$. Relative to other diseases,

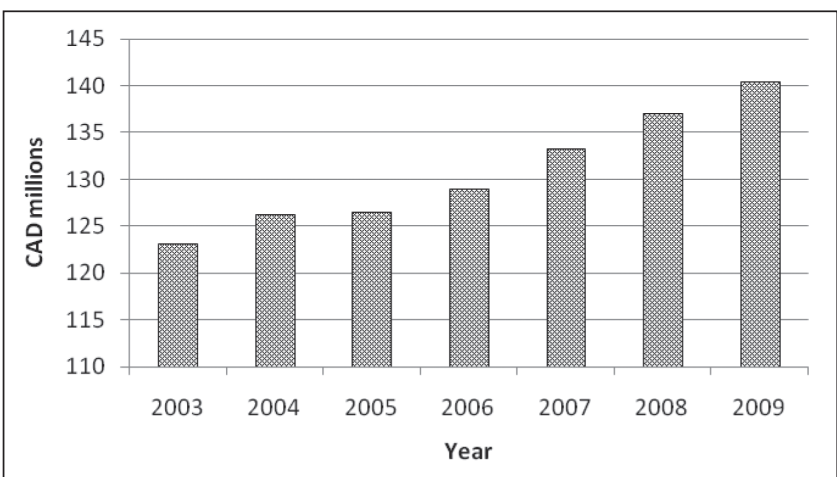

Figure 2) Retail market (\$) for over-the-counter indigestion and heartburn remedies in Canada according to year

the GERD cohort had physical scores similar to individuals with clinical depression or hypertension, while mental scores were significantly worse $(\mathrm{P}<0.001)$ than hypertensive or diabetic patients.

The frequency of GERD patients who develop cancer from associated dysplastic Barrett's epithelium is low, suggesting that routine endoscopic screening of this population group is not warranted (21). In turn, this represents a considerable cost savings to a health care insurer because a single endoscopy procedure costs \$575 (Ambulatory care classification system 28.1) (22).

For pediatric patients, GERD can be successfully treated with proton pump inhibitors and, in severe cases, surgical intervention may be required $(17,23)$; however, surgery of this nature on young patients is associated with comorbidity and failure.

At any age, GERD diagnosis represents a considerable longterm expense for the health insurer and the patient; however, prompt diagnosis in the very young is essential to reduce health care burdens and reduce the need for surgical interventions (17).

\section{REFERENCES}

1. Frank L, Kleinman L, Ganoczy D, et al. Upper gastrointestinal symptoms in North America: Prevalence and relationship to healthcare utilization and quality of life. Dig Dis Sci 2000;45:809-18.

2. Armstrong D, Marshall JK, Chiba N, et al. Canadian Consensus Conference on the management of gastroesophageal reflux disease in adults - update 2004. Can J Gastroenterol 2005;19:15-35.

3. Bardhan KD. The role of proton pump inhibitors in the treatment of gastro-oesophageal reflux disease. Aliment Pharmacol Ther 1995;9(Suppl 1):15-25

4. Martinez SD, Malagon IB, Garewal HS, Cui H, Fass R. Non-erosive reflux disease (NERD) - acid reflux and symptom patterns. Aliment Pharmacol Ther 2003;17:537-45.

5. Ruigomez A, Garcia Rodriguez LA, Wallander MA, Johansson S, Dent J. Comparison of gastro-oesophageal reflux disease and heartburn diagnoses in UK primary care. Curr Med Res Opin 2006;22:1661-8.

6. Kotzan J, Wade W, Yu HH. Assessing NSAID prescription use as a predisposing factor for gastroesophageal reflux disease in a Medicaid population. Pharm Res 2001;18:1367-72.

7. Heading RC. Epidemiology of oesophageal reflux disease. Scand J Gastroenterol Suppl 1989;168:33-7.

8. Belanger A, Martel L, Caron-Malenfant E. Population projections for Canada, Provinces and Territories, 2005-2031. Statistics Canada (91-520-XIE), 2005.

9. Nelson SP, Kothari S, Wu EQ, Beaulieu N, McHale JM, Dabbous $\mathrm{OH}$. Pediatric gastroesophageal reflux disease and acid-related conditions: Trends in incidence of diagnosis and acid suppression therapy. J Med Econ 2009;12:348-55. 
10. Kothari S, Nelson SP, Wu EQ, Beaulieu N, McHale JM, Dabbous OH. Healthcare costs of GERD and acid-related conditions in pediatric patients, with comparison between histamine-2 receptor antagonists and proton pump inhibitors. Curr Med Res Opin 2009;25:2703-9.

11. Statistics Canada. Population by sex and age group, CANSIM, Table 051-0001. <http://www40.statcan.gc.ca/101/cst01/demo10aeng.htm> (Accessed on May 14, 2010).

12. Armstrong D. Systematic review: Persistence and severity in gastrooesophageal reflux disease. Aliment Pharmacol Ther 2008;28:841-53.

13. Organisation for Economic Co-operation and Development (OECD). OECD Health Data 2009. <http://www.oecd.org> (Accessed on May 14, 2010).

14. Statistics Canada. CANSIM - Table 102-0531 - Deaths, by cause, Chapter XI: Diseases of the digestive system (K00 to K93), age group and sex, Canada, annual (2000-2005). <http://cansim2. statcan.gc.ca> (Accessed on May 14, 2010).

15. Canadian Institute for Health Information. The Cost of Hospital Stays: Why Costs Vary. Ottawa: CIHI Press, 2008.

16. Bursey F, Crowley M, Janes C, Turner CJ. Cost analysis of a provincial drug program to guide the treatment of upper gastrointestinal disorders. CMAJ 2000;162:817-23.

17. Gold BD. Review article: Epidemiology and management of gastro-oesophageal reflux in children. Aliment Pharmacol Ther 2004;19(Suppl 1):22-7.

18. Raghunath AS, O'Morain C, McLoughlin RC.

Review article: The long-term use of proton-pump inhibitors. Aliment Pharmacol Ther 2005;22:55-63.
19. Canadian Agency for Drugs and Technologies in Health. Proton pump inhibitors. $<$ http://www.cadth.ca/index.php/en/compus/ppis $>$ (Accessed on May 14, 2010).

20. El-Dika S, Guyatt GH, Armstrong D, et al. The impact of illness in patients with moderate to severe gastro-esophageal reflux disease. BMC Gastroenterol 2005;5:23.

21. Shaheen N, Ransohoff DF. Gastroesophageal reflux, Barrett esophagus, and esophageal cancer: Scientific review. JAMA 2002;287:1972-81.

22. Health Authority Funding and Financial Accountability. Health Costing in Alberta 2006 Annual Report. 2007. Alberta Health and Wellness. <http://www.hc-sc.gc.ca/hcs-sss/pubs/chalcs/2006-cha-lcs-ar-ra/ab-eng.php> (Accessed on June 7, 2010).

23. Hassall $\mathrm{E}$. Decisions in diagnosing and managing chronic gastroesophageal reflux disease in children. J Pediatr 2005;146:S3-12.

24. Dent J, El-Serag HB, Wallander MA, Johansson S. Epidemiology of gastro-oesophageal reflux disease: A systematic review. Gut 2005;54:710-7.

25. Eslick GD, Talley NJ. Gastroesophageal reflux disease (GERD): Risk factors, and impact on quality of life - a population-based study. J Clin Gastroenterol 2009;43:111-7.

26. Molina EJ, Short S, Monteiro G, Gaughan JP, Macha M. Symptomatic gastroesophageal reflux disease after lung transplantation. Gen Thorac Cardiovasc Surg 2009;57:647-53.

27. Blondeau K, Pauwels A, Dupont L, et al. Characteristics of gastroesophageal reflux and potential risk of gastric content aspiration in children with cystic fibrosis. J Pediatr Gastroenterol Nutr 2010;50:161-6. 


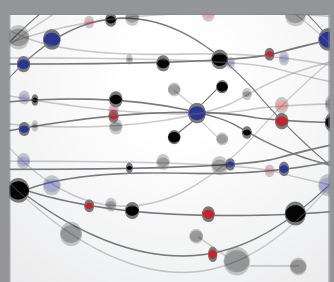

The Scientific World Journal
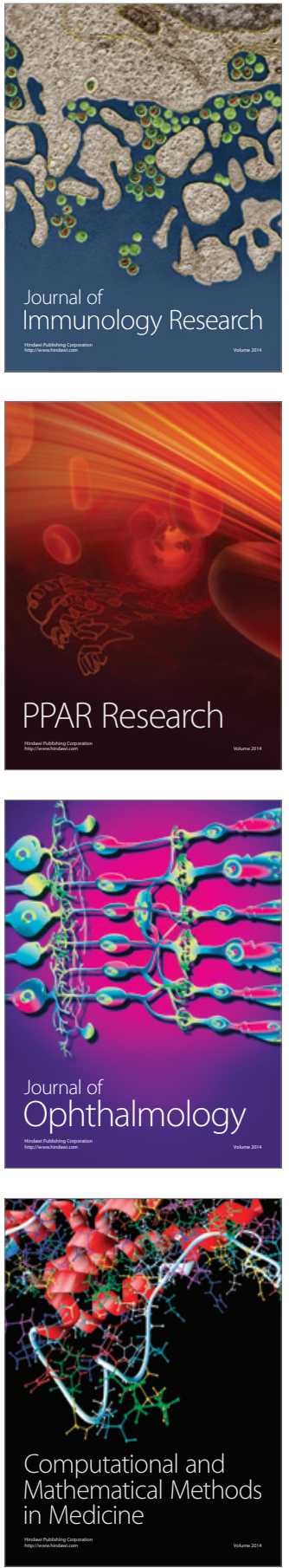

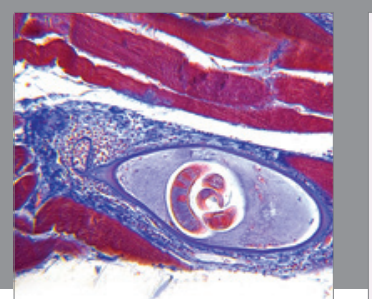

Gastroenterology Research and Practice

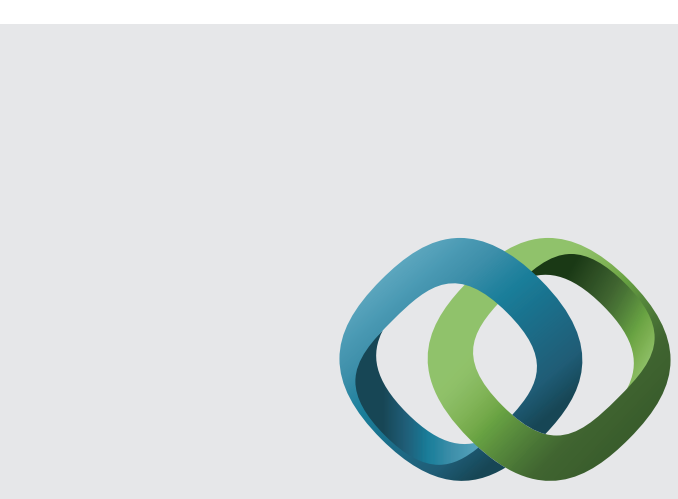

\section{Hindawi}

Submit your manuscripts at

http://www.hindawi.com
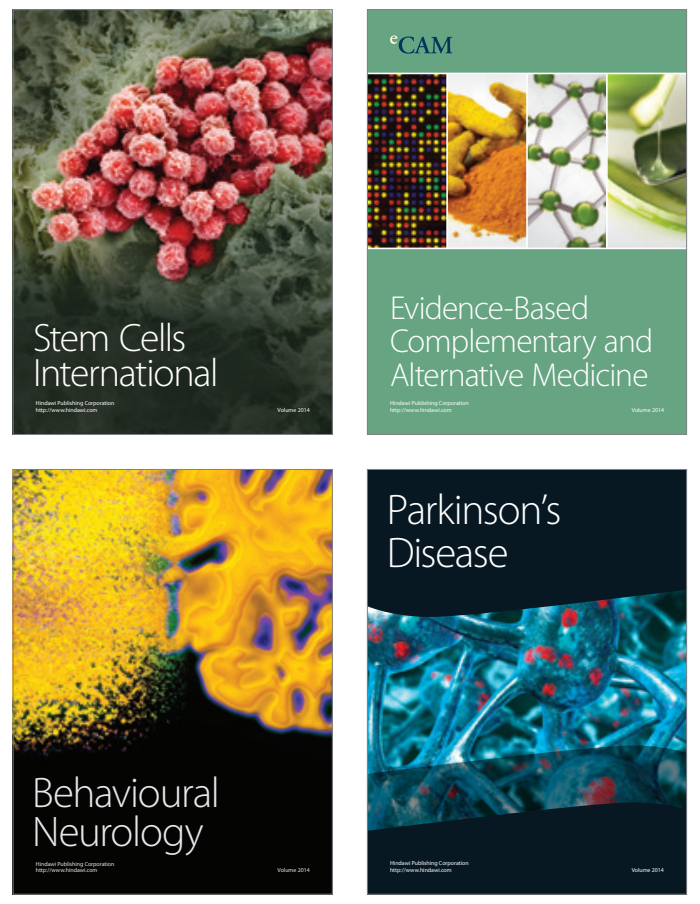
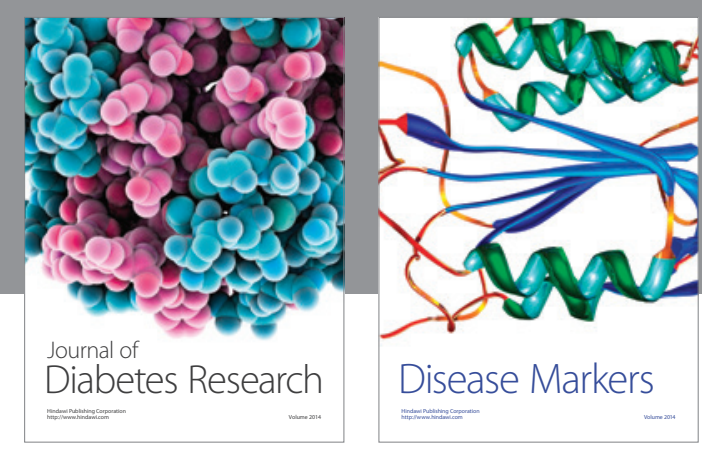

Disease Markers
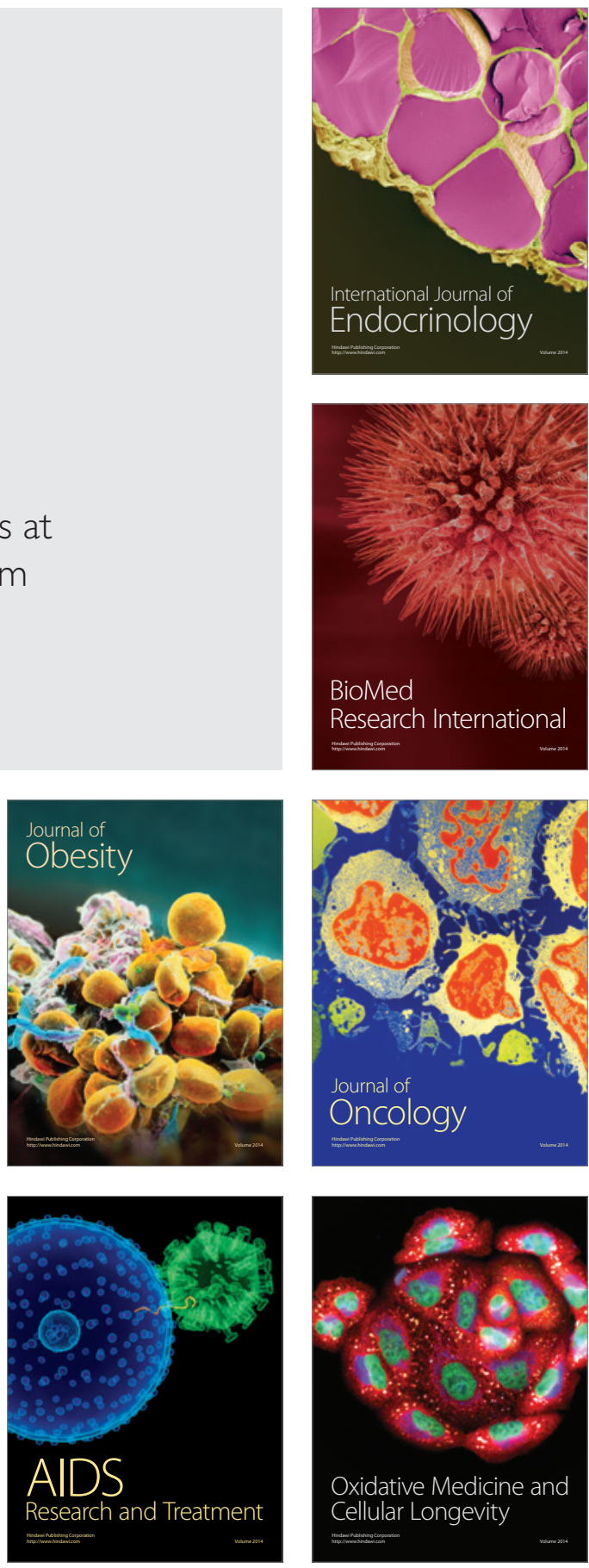